\title{
Lake sediment multi-taxon DNA from North Greenland records early post-glacial appearance of vascular plants and accurately tracks environmental changes
}

\author{
L.S. Epp a, b, *, G. Gussarova ${ }^{\text {a, c }}$, S. Boessenkool ${ }^{\text {a, } 1}$, J. Olsen ${ }^{\text {d }}$, J. Haile ${ }^{\text {e, f }}$, \\ A. Schrøder-Nielsen ${ }^{a}$, A. Ludikova ${ }^{g}$, K. Hassel ${ }^{\text {h }}$, H.K. Stenøien ${ }^{\text {h }}$, S. Funder ${ }^{\text {, }}$, \\ E. Willerslev ${ }^{\mathrm{e}}$, K. Kjær ${ }^{\mathrm{e}}$, C. Brochmann ${ }^{\mathrm{a}}$ \\ ${ }^{a}$ Natural History Museum, University of Oslo, PO Box 1172 Blindern, NO-0318 Oslo, Norway \\ b Alfred Wegener Institute Helmholtz Centre for Polar and Marine Research, Periglacial Research, Am Telegrafenberg A43, 14473 Potsdam, Germany \\ ${ }^{c}$ Department of Botany, St Petersburg State University, Universitetskaya nab. 7/9, 199034 St Petersburg, Russia \\ ${ }^{\mathrm{d}}$ AMS ${ }^{14} \mathrm{C}$ Dating Centre, Department of Physics and Astronomy, Aarhus University, Ny Munkegade 120, DK-8000 Aarhus C, Denmark \\ e Centre of Excellence for GeoGenetics, Natural History Museum of Denmark, Øster Voldgade 5-7, 1350 Copenhagen K, Denmark \\ ${ }^{\mathrm{f}}$ TrEnD Laboratory, Curtin University, Bentley, Perth, Western Australia, Australia \\ ${ }^{g}$ Institute of Limnology, Russian Academy of Sciences, Sevastyanova str., 9, 196105 St Petersburg, Russia \\ ${ }^{\mathrm{h}}$ Natural History Department, NTNU University Museum, Norwegian University of Science and Technology, NO-7491 Trondheim, Norway
}

\section{A R T I C L E I N F O}

\section{Article history:}

Received 17 December 2014

Received in revised form

30 March 2015

Accepted 31 March 2015

Available online

\section{Keywords}

Sedimentary DNA

Metabarcoding

Greenland

Vegetation history

Bryophytes

Diatoms

Copepods

\begin{abstract}
A B S T R A C T
High Arctic environments are particularly sensitive to climate changes, but retrieval of paleoecological data is challenging due to low productivity and biomass. At the same time, Arctic soils and sediments have proven exceptional for long-term DNA preservation due to their constantly low temperatures. Lake sediments contain DNA paleorecords of the surrounding ecosystems and can be used to retrieve a variety of organismal groups from a single sample. In this study, we analyzed vascular plant, bryophyte, algal (in particular diatom) and copepod DNA retrieved from a sediment core spanning the Holocene, taken from Bliss Lake on the northernmost coast of Greenland. A previous multi-proxy study including microscopic diatom analyses showed that this lake experienced changes between marine and lacustrine conditions. We inferred the same environmental changes from algal DNA preserved in the sediment core. Our DNA record was stratigraphically coherent, with no indication of leaching between layers, and our cross-taxon comparisons were in accordance with previously inferred local ecosystem changes. Authentic ancient plant DNA was retrieved from nearly all layers, both from the marine and the limnic phases, and distinct temporal changes in plant presence were recovered. The plant DNA was mostly in agreement with expected vegetation history, but very early occurrences of vascular plants, including the woody Empetrum nigrum, document terrestrial vegetation very shortly after glacial retreat. Our study shows that multitaxon metabarcoding of sedimentary ancient DNA from lake cores is a valuable tool both for terrestrial and aquatic paleoecology, even in low-productivity ecosystems such as the High Arctic.
\end{abstract}

(c) 2015 Elsevier Ltd. All rights reserved.

\footnotetext{
* Corresponding author. Alfred Wegener Institute Helmholtz Centre for Polar and Marine Research, Periglacial Research, Am Telegrafenberg A43, 14473 Potsdam, Germany. Tel.: +49 331288 2208; fax: +49 3312882137.

E-mail address: laura.epp@awi.de (L.S. Epp).

1 Present address: Centre for Ecological and Evolutionary Synthesis, Department of Biosciences, University of Oslo, PO Box 1066 Blindern, NO-0318 Oslo, Norway.
}

\section{Introduction}

The High Arctic is currently experiencing severe changes in climate and environment, with unprecedented rates of warming in areas such as northernmost Greenland (Perren et al., 2012). This has important implications for the biota of these regions (Klein et al., 2008; Nielsen and Wall, 2013). Major changes in climate and species distributions have previously occurred during the Pleistocene glacial-interglacial cycles (Brochmann et al., 2003; Kienast et al., 2011), which served as important drivers of past and current 
population structure (Hewitt, 2004; Eidesen et al., 2013). Climate and ecosystem perturbations also characterized the Holocene (Kaufman et al., 2009; Funder et al., 2011). As the High Arctic harbors ecosystems with low diversity and little direct anthropogenic influence, effects of climate changes are particularly pronounced (Callaghan et al., 2004; Wall, 2007), and it is predicted that future changes due to global warming will be substantial (ACIA, 2005). Therefore, investigating previous ecosystem changes and timing of species establishment in the High Arctic are highly relevant to understand and forecast possible consequences of future climate warming.

Paleoecological archives, such as lacustrine and marine sediment cores, provide a valuable source of data (Willis et al., 2010). They record the history of vegetation cover and terrestrial ecosystem changes, as well as changes in aquatic communities, which are sensitive indicators of changing environmental conditions (Smol and Cumming, 2000). Unfortunately, studies of past biotic changes in the low-productivity ecosystems of the High Arctic are often impeded by the lack or scarcity of organismal remains (Funder and Abrahamsen, 1988; Wagner et al., 2008). An additional problem at the limits of species distributions, such as in the Arctic, is diminished rate of sexual reproduction under unfavorable conditions (Klein et al., 2008), resulting in a poor pollen record. Finally, harsh conditions and low nutrient availability result in low growth rates and low biomass of aquatic organisms (Smol, 1983). Therefore, although studies of past algal communities, in particular of diatoms, are useful in Arctic paleoecology (Douglas and Smol, 1999; Smol et al., 2005), microscopic data can be difficult to obtain.

In recent years, the analysis of ancient DNA (aDNA) isolated directly from sediments has become a valuable addition to the toolbox for analyzing organismal records through time. It offers complementary data to existing paleoecological tools, such as pollen analysis (e.g. Jørgensen et al., 2012). Furthermore, the potentially high sensitivity of this approach, which allows detection of organisms even in the absence of visible remains (Willerslev et al., 2003; Haile et al., 2009), makes sedimentary ancient DNA (sedaDNA, Haile et al., 2009) particularly promising for the study of ecosystem changes in low-productivity settings such as in the High Arctic. DNA can be retrieved both from terrestrially deposited soils and sediments (e.g. Willerslev et al., 2003; Sønstebø et al., 2010; Willerslev et al., 2014) and from lacustrine and marine sediment cores (e.g. Coolen et al., 2013; Parducci et al., 2013; Boessenkool et al., 2014). The use of sedaDNA to analyze paleorecords has become feasible for large numbers of samples and multiple organismal groups, thanks to high-throughput sequencing technologies coupled with optimized markers for species identification. This approach, termed DNA metabarcoding (Taberlet et al., 2012), has enabled the parallel retrieval of large amounts of informative data (e.g. Binladen et al., 2007; Valentini et al., 2009; Willerslev et al., 2014). DNA from both plants and plankton has been found in sediment cores spanning centennial to millennial time scales at lower latitudes (e.g. Epp et al., 2010; Stoof-Leichsenring et al., 2012; Boessenkool et al., 2014; Giguet-Covex et al., 2014), but highlatitude lakes, such as in the Arctic, can supposedly yield results going back further in time, because conditions for DNA preservation are optimal under cold conditions (Lindahl, 1993; Pääbo et al., 2004; Willerslev et al., 2004; Hofreiter et al., 2012).

In the present study, we examined the DNA record throughout a sediment core from the High Arctic Bliss Lake, which has previously been analyzed using sedimentological methods and classical diatom analyses (Olsen et al., 2012). This sediment core spans the Holocene of one of the northernmost lakes in the world, located in Peary Land in the far north of Greenland, on a coastal plain facing the Arctic Ocean (Fig. 1). Peary Land is the landmass closest to the
North Pole, with currently extreme conditions and land-fast sea ice. Due to its remoteness, paleoecological investigations from this area, in particular of lacustrine sediment cores, are rare (Olsen et al., 2012). Continuous sedimentary records spanning the complete Holocene are uncommon in northern Greenland, because deglaciation, lake formation and the onset of sedimentation commonly fall within the early Holocene (Cremer et al., 2008; Larsen et al., 2010; Möller et al., 2010). The formation of Bliss Lake is assumed to be concurrent with the general deglaciation of North Greenland, at ca 11,000 cal yr BP (Larsen et al., 2010; Möller et al., 2010), and throughout the Holocene it experienced a series of distinct environmental shifts (Olsen et al., 2012). It started as a marine embayment with brackish conditions, caused by shelf-based ice off the coast of North Greenland and a high inflow of melt water (termed zone 1 by Olsen et al., 2012). Full inundation by the ocean at ca 10,500 cal yr BP led to a phase when the current lake was a marine bay (zone 2). Finally, at ca 7200 cal yr BP, the lake became isolated from the ocean, and lacustrine conditions have prevailed to this day (zone 3 ).

The Bliss Lake sediment core is a rare archive of the Holocene environmental history of Northern Greenland, and it is uniquely suited to test the power and sensitivity of DNA-based approaches to analyze changing environmental conditions through time in lowproductivity ecosystems. We analyzed the record using a multitaxon metabarcoding approach with primers designed for vascular plants, bryophytes, diatoms and copepods. We aimed to trace the terrestrial and aquatic ecosystem history throughout the Holocene in this remote part of Greenland, and to assess the potential of multi-taxon metabarcoding in such extreme lowproductivity ecosystems.

\section{Regional setting}

Bliss Lake ( $83^{\circ} 31.227^{\prime} \mathrm{N}, 28^{\circ} 21.201^{\prime} \mathrm{W}, 17 \mathrm{~m}$ above sea level (a.s.l.), Fig. 1) is described in detail in Olsen et al. (2012). The lake has a maximum depth of $9.8 \mathrm{~m}$ and is presently ice-covered yearround, with a mid July ice thickness measured to $158 \mathrm{~cm}$. It is located on the coastal plain of Peary Land, which separates the interior ice-covered mountains from the Arctic Ocean. This coastal plain of northeast Greenland is characterized by extreme climatic and environmental conditions. At nearby Kap Morris Jesup the mean annual temperature and the average of the warmest month are $-19{ }^{\circ} \mathrm{C}$ and $1{ }^{\circ} \mathrm{C}$, respectively (Cappelen and Jensen, 2001). The vegetation is sparse polar desert with only ca $5 \%$ coverage of plants over the barren ground (Bay, 1992). The vascular plant vegetation on the plain is dominated by saxifrages, notably Saxifraga oppositifolia, as well as Papaver, Oxyria, and species of the Caryophyllaceae and Brassicaceae. In sheltered habitats, patches of High Arctic dwarf shrubs can be found, with the woody species Salix arctica, Cassiope tetragona and Dryas integrifolia (Bay, 1992), but we have not observed any of these in the drainage area of Bliss Lake.

\section{Material and methods}

\subsection{Sampling}

The sediment core was collected in 2006 from the deepest part of the lake using a percussion corer with a diameter of $8 \mathrm{~cm}$. A total of $331.5 \mathrm{~cm}$ was retrieved. The core was stored in a cool room until sampling. For sampling, the core was split into two halves, and samples for different sedimentological analyses were taken from within. For the present study, a total of 20 samples were taken for DNA extraction with sterile scalpels after carefully removing the exposed layer of sediment on the inside of the core (Table 1). 


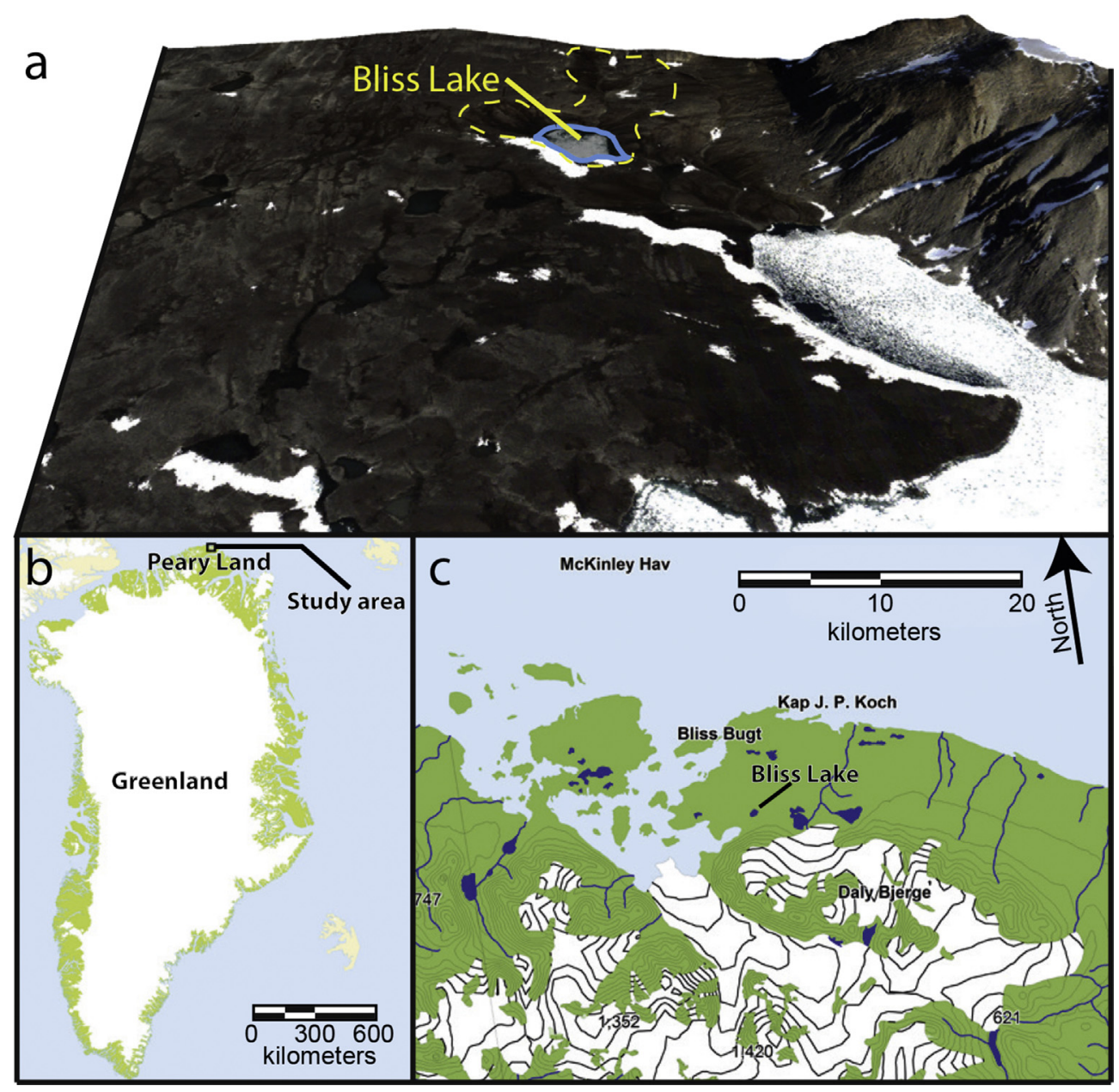

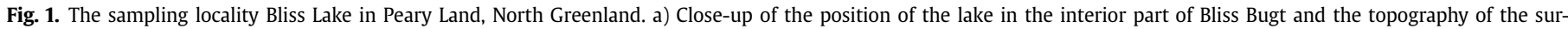

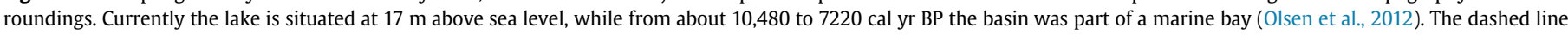
shows the approximate catchment area of Bliss Lake. b) Map of Greenland with indication of the study area in the far north, and c) detail of the study area.

\subsection{Chronology}

The chronology of Bliss Lake is based on 24 AMS ${ }^{14} \mathrm{C}$ measurements performed at the accelerator mass spectrometry (AMS) ${ }^{14} \mathrm{C}$ Dating Centre at Aarhus University. Dating was done on both macrofossils and on chemical bulk fractions (humic acid and humic acid residue). Details of sample treatment and age model construction are provided by Olsen et al. (2012). Calibrated ages are given as cal yr BP.

\subsection{Molecular genetic laboratory work}

Sampling and DNA extraction were carried out at the Centre for Geogenetics, University of Copenhagen, in facilities dedicated to work with aDNA. Extraction of total DNA was carried out using the PowerMax ${ }^{\mathrm{TM}}$ Soil DNA Isolation Kit (MOBIO) with protocol modifications described in Epp et al. (2012), and included one extraction blank containing only the chemicals. PCRs were set up in the dedicated aDNA laboratory at the Natural History Museum in Oslo. PCR reactions were performed in $25 \mu$ l volumes containing $1.25 \mathrm{U}$ Platinum $^{\circledR}$ Taq High Fidelity DNA Polymerase (Invitrogen), $1 \times$ PCR buffer, $2 \mathrm{mM} \mathrm{MgSO}_{4}, 1 \mathrm{mM}$ dNTPs, $0.2 \mu \mathrm{M}$ of each primer, $0.8 \mathrm{mg} / \mathrm{ml}$ Bovine Serum Albumin (BSA) and $3 \mu$ DNA extract, using primers with high specificity either to vascular plants, bryophytes, diatoms or copepods (Table 2). PCR blanks and the extraction blank were run alongside the PCRs containing template DNA. The primers for vascular plants, bryophytes and diatoms were designed as fusion primers, carrying the Roche 454 Lib-L adapters and Roche MID tags on one primer for pooling of multiple samples in 454 amplicon sequencing. The primers for copepods carried unique 6 bp tags on both primers, and Roche Lib-L adapters were ligated prior to sequencing. PCR conditions were $2 \mathrm{~min}$ at $94^{\circ} \mathrm{C}$, followed by $50-55$ cycles of $94{ }^{\circ} \mathrm{C}$ for $30 \mathrm{~s}, \mathrm{~T}_{\mathrm{a}}$ (Table 1 ) for $30 \mathrm{~s}, 68^{\circ} \mathrm{C}$ for $30 \mathrm{~s}$, and final extension for $10 \mathrm{~min}$ at $72{ }^{\circ} \mathrm{C}$. For each sample and primer pair, amplification was attempted up to five times. As soon as two positive and strong amplifications were obtained, these were used for sequencing. If we did not obtain two positive amplifications after five attempts, the sample was discarded for that particular primer pair. As a result, the total number of samples sequenced per primer pair varies (Table 1 ; vascular plants: 20 , bryophytes: 7 , diatoms: 18 , copepods: 3 ). The two positive amplifications were mixed, purified and pooled in equimolar concentrations for sequencing on a Roche 454 GS FLX Titanium platform. Purification and normalization of the PCR products was performed using either the SequalPrep ${ }^{\mathrm{TM}}$ Normalization Plate Kit (Invitrogen) or the Agencourt AMPure XP system (Beckman Coulter) for purification, followed by manual normalization after concentration measurement with a Qubit ${ }^{\circledR} 2.0$ fluorometer (Invitrogen). Sequencing was conducted either at the Norwegian Sequencing Centre, University of Oslo, or by Beckman Coulter Genomics (see Table A.1 for the specific treatment and 
Table 1

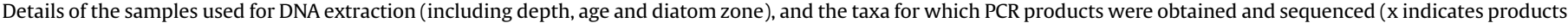
were sequenced, - indicates no products were sequenced for this respective taxon).

\begin{tabular}{|c|c|c|c|c|c|c|c|c|}
\hline \multirow[b]{2}{*}{$\begin{array}{l}\text { DNA } \\
\text { sample }\end{array}$} & \multicolumn{8}{|c|}{ PCR products sequenced for } \\
\hline & $\begin{array}{l}\text { depth } \\
(\mathrm{cm})\end{array}$ & $\begin{array}{l}\text { Age } \\
\text { (cal BP) }\end{array}$ & $\begin{array}{l}\text { diatom } \\
\text { zone }^{*}\end{array}$ & $\begin{array}{l}\text { vascular } \\
\text { plants } 1\end{array}$ & $\begin{array}{l}\text { vascular } \\
\text { plants } 2\end{array}$ & bryophytes & diatoms & copepods \\
\hline 20 & $18-19$ & $442 \pm 139$ & \multirow{9}{*}{ Zone 3} & $\mathbf{x}$ & $\mathbf{x}$ & $\mathbf{x}$ & $\mathbf{x}$ & - \\
\hline 19 & $31-32$ & $718 \pm 162$ & & $\mathbf{x}$ & $\mathbf{x}$ & $\mathbf{x}$ & $\mathbf{x}$ & - \\
\hline 18 & $55-56$ & $1228 \pm 184$ & & $\mathbf{x}$ & $\mathbf{x}$ & $\mathbf{x}$ & $\mathbf{x}$ & - \\
\hline 17 & $70-71$ & $1546 \pm 189$ & & $\mathbf{x}$ & $\mathbf{x}$ & - & - & - \\
\hline 16 & $125-126$ & $2714 \pm 142$ & & $\mathbf{x}$ & $\mathbf{x}$ & $\mathbf{x}$ & $\mathbf{x}$ & - \\
\hline 15 & $157-158$ & $4131 \pm 240$ & & $\mathbf{x}$ & $\mathbf{x}$ & $\mathbf{x}$ & $\mathbf{x}$ & - \\
\hline 14 & $176-177$ & $5485 \pm 260$ & & $\mathbf{x}$ & $\mathbf{x}$ & - & - & - \\
\hline 13 & 198-199 & $6891 \pm 121$ & & $\mathbf{x}$ & $\mathbf{x}$ & $\mathbf{x}$ & $\mathbf{x}$ & - \\
\hline 12 & $206-207$ & $7119 \pm 148$ & & $\mathbf{x}$ & $\mathbf{x}$ & - & $\mathbf{x}$ & - \\
\hline 11 & $215-217$ & $7413 \pm 155$ & \multirow{8}{*}{ Zone 2} & $\mathbf{x}$ & $\mathbf{x}$ & - & $\mathbf{x}$ & $\mathbf{x}$ \\
\hline 10 & $226-227$ & $7754 \pm 129$ & & $\mathbf{x}$ & $\mathbf{x}$ & $\mathbf{x}$ & $\mathbf{x}$ & - \\
\hline 9 & $234-236$ & $8033 \pm 116$ & & $\mathbf{x}$ & $\mathbf{x}$ & - & $\mathbf{x}$ & - \\
\hline 8 & $245-247$ & $8397 \pm 143$ & & $\mathbf{x}$ & $\mathbf{x}$ & - & $\mathbf{x}$ & $\mathbf{x}$ \\
\hline 7 & $253-255$ & $8662 \pm 133$ & & $\mathbf{x}$ & $\mathbf{x}$ & - & $\mathbf{x}$ & - \\
\hline 6 & $265-268$ & $9176 \pm 168$ & & $\mathbf{x}$ & $\mathbf{x}$ & - & $\mathbf{x}$ & - \\
\hline 5 & $275-277$ & $9703 \pm 228$ & & $\mathbf{x}$ & $\mathbf{x}$ & - & $\mathbf{x}$ & - \\
\hline 4 & $285-287$ & $10257 \pm 214$ & & $\mathbf{x}$ & $\mathbf{x}$ & - & $\mathbf{x}$ & - \\
\hline 3 & $289-291$ & $10478 \pm 188$ & \multirow{3}{*}{ Zone 1} & $\mathbf{x}$ & $\mathbf{x}$ & - & $\mathbf{x}$ & - \\
\hline 2 & $309-311$ & $10676 \pm 110$ & & $\mathbf{x}$ & $\mathbf{x}$ & - & $\mathbf{x}$ & $\mathbf{x}$ \\
\hline 1 & $330-331$ & $10846 \pm 105$ & & $\mathbf{x}$ & $\mathbf{x}$ & - & $\mathbf{x}$ & - \\
\hline
\end{tabular}

Table 2

Details of the amplification primers used in this study. Target taxon, primer names, annealing temperature ( $\left.T_{a}\right)$ and original reference are provided.

\begin{tabular}{llll}
\hline Taxon & Primers & $\mathrm{T}_{\mathrm{a}}$ & Reference \\
\hline Vascular plants & trnL-g \& trnL-h & $50{ }^{\circ} \mathrm{C}$ \\
Bryophytes & bryo_P6F_1 \& bryo_P6R & $50{ }^{\circ} \mathrm{C}$ & Taberlet et al., 2007 \\
Diatoms & rbcL_705f \& rbcl_808r & $44{ }^{\circ} \mathrm{C}$ & Epp et al., 2012 \\
Copepods & CopF2 \& CopR1 & $61{ }^{\circ} \mathrm{C}$ & Stoof-Leichsenring et al., 2012 \\
\hline
\end{tabular}

a Bryo_P6F_1 modified to include two ambiguous bases: ATTCAGGGAAACYTARGTTG.

sequencing of the different PCR products). For the vascular plant DNA we conducted two rounds of PCR and sequencing (referred to as vascular plant dataset 1 and 2, abbreviated vp1 and vp2). Because the two runs of vascular plant DNA were not produced using identical protocols (see below), we do not consider them full replicates, but merge the data for the final interpretation.

All experiments were carried out adhering to standard aDNA precautions. In addition, the majority of PCR chemicals were decontaminated as outlined in Champlot et al. (2010), minimizing DNA contamination from laboratory equipment and PCR chemicals. Primers and dNTPs, but not the polymerase, were treated with heat-labile double-strand specific DNase (ArcticZymes). The BSA, $\mathrm{MgSO}_{4}, 10 \times$ buffer and DEPC-treated water were UV irradiated for $10 \mathrm{~min}$ in a UV crosslinker in thin-walled PCR strips. Exceptions were the chemicals used to produce vascular plant dataset 1 , and the bryophyte primers. In each round of vascular plant PCRs, bands were observed in some of the PCRs of the extraction blanks and in some of the PCR blanks. To monitor the contamination, we did not discard these reactions, but rather took a conservative approach and sequenced all PCR reactions from extraction blanks and PCR blanks for the vascular plant, bryophyte and diatom reactions, no matter if they were positive or not.

\subsection{Analysis of sequence data and taxonomic assignments}

Sequence data was filtered and sorted with programs from the OBITools package (http://metabarcoding.org/obitools). Potential PCR and sequencing errors were removed using the program obiclean. After filtering, all sequences that appeared in any of the sequenced blanks were excluded from the dataset, and taxonomic assignments were performed against taxonomic reference libraries using the program ecotag (part of the OBITools package) and/or by BLASTn (Altschul et al., 1997) searches against GenBank. The ecotag analysis of vascular plants and bryophytes was based primarily on quality-checked and curated reference libraries for arctic and boreal species constructed at the Natural History Museum in Oslo (arctic vascular plants: Sønstebø et al., 2010; boreal vascular plants: Willerslev et al., 2014; bryophytes: Soininen et al., 2015). These libraries contain 1664 vascular plant species and 486 bryophyte species. In addition, reference libraries for each organism group were created with each of the primer pairs from the EMBL Nucleotide Database standard release 113 by extracting sequences of the targeted region using ecoPCR (Ficetola et al., 2010). To maximize the number of sequences in the EMBL-based reference libraries, we allowed five mismatches between primers and target sequences in 
the ecoPCR analyses. Taxonomical assignments were also used to discard possible erroneous sequences or artifacts from the dataset, by removing sequences with similarity below a defined identity threshold to any sequence in the reference library (see Appendix A.1 for details). All analyses were performed using the computing facilities of the Norwegian Metacenter for Computational Science (Notur). All filtered sequences with their taxonomic identity as inferred by the program ecotag have been deposited in the Dryad Digital Repository: http://dx.doi.org/10.5061/dryad.26h7b.

The automated taxonomic annotation was manually checked to exclude potential contaminants. Plant sequences were considered to be potential contaminants and excluded from the interpretation, if they were: 1) also present in a blank, 2) identical to sequences from food or cultivated plants, 3) highly unlikely to have been present in northernmost Greenland at any time during the Holocene, based on detailed floristic knowledge of the area, on our own observations during several field seasons and on the Panarctic Flora Checklist (Elven et al., 2011). We also fine-tuned the taxonomic assignments according to the geographic distribution of identified taxa (Elven et al., 2011) coupled with an evaluation of the completeness of our circumarctic/circumboreal reference libraries (e.g., if the library only contained one of two congeneric species likely to occur in our study area, we assigned the sequence to the species group level rather than to the species level). If two sequences were identified to the same taxon, but had a $100 \%$ identity to different reference sequences within this taxon, they were identified to the same taxon, but indicated as different molecular operational taxonomic units (MOTUs, Floyd et al., 2002).

All diatom sequence types retained after filtering were considered as MOTUs and a matrix containing these MOTUs was subjected to statistical analyses (see below). Only MOTUs with a best identity in ecotag of 0.95 or more were taxonomically annotated. Further information on filtering of diatom sequences is provided in Appendix A.1. Due to the fact that taphonomical biases, as well as biases introduced in the PCR reactions, are largely unexplored to date for sedaDNA, we base all further analyses and the inferences for all analyzed taxa solely on presence data of the retrieved sequence types. Sequence type abundances (i.e. number of reads) are nonetheless reported in the Appendices B.1-B.5.

\subsection{Statistical analyzes}

The multivariate ordination techniques Principal Component Analysis (PCA) and Redundancy Analysis (RDA) were applied to two datasets. The first dataset, including only DNA-based data retrieved with the diatom primers, was analyzed with PCA to compare all sediment samples according to their diatom community composition. The second dataset, including physical, chemical and geological data retrieved through sedimentological analyses (see below, Olsen et al., 2012) together with DNA-based data, was analyzed with RDA to test for relationships between community composition and paleoenvironmental conditions. The analyses were run in $\mathrm{R} v$. 2.14.1 (R Core Team, 2013) using the package "vegan" (Oksanen et al., 2013).

For all analyses, original abundances of the 176 algal MOTUs that were retrieved from 18 samples were reduced to presence/ absence data. To ensure that the sample ordination pattern was not influenced by null abundances, Hellinger distance transformation (Rao, 1995) was applied, using the "decostand" function of the "vegan" package (Oksanen et al., 2013). The transformed presence/absence data were subsequently analyzed with PCA as recommended by Legendre and Gallagher (2001). In an initial PCA run on the total algal dataset, many MOTUs showed identical factor loading values. We merged these MOTUs into 17 MOTU groups (named with group number followed by number of individual MOTUs that were included in this group; Appendix B.6) and ran a final PCA with Hellinger distance transformation (Appendix C.1) on this dataset comprising in total 33 MOTUs/ MOTU groups.

The physical, chemical and geological data included in the RDA to test for relationships between community composition and paleoenvironmental conditions were originally assembled by Olsen et al. (2012) to investigate palaeolimnological conditions of the lake through time. These included X-ray fluorescence (XRF) data of a number of elements (e.g. Ti, $\mathrm{K}, \mathrm{Ca}, \mathrm{Fe}, \mathrm{S}, \mathrm{Br}, \mathrm{Cl})$, organic matter $(\mathrm{OM})$, total organic carbon (TOC), total nitrogen (TN), total sulphur (TS) and carbon isotope ratios $\left(\delta^{13} \mathrm{C}\right)$. Emphasis was placed upon elements that can differentiate between marine and lacustrine phases, such as $\mathrm{S}$ and $\mathrm{Br}$, which are more abundant in marine environments, and on redox sensitive elements, such as Fe and S. The selection included elements that originate from the catchment and characterize the delivery of sediments to the lake, while not participating in chemical reactions (such as Ti and $\mathrm{K}$ ), and elements that derive from the catchment but are influenced by chemical processes within the lake (such as $\mathrm{Ca}$ and $\mathrm{Fe}$ ). To reach concentration values that reflect the autochthonous input of the respective chemically active elements, they are therefore normalized. For example, Ca may precipitate due to changes in $\mathrm{pH}$ as a result of organic productivity. Normalizing $\mathrm{Ca}$ with $\mathrm{Ti}(\mathrm{Ca} / \mathrm{Ti}$ ratio), the terrestrial component to Ca variability is removed, and the $\mathrm{Ca} / \mathrm{Ti}$ ratio reflects autochthonous Ca. Normalization was also carried out for organic matter content, which may originate from both inlake and terrigeneous processes. Here the $\mathrm{C} / \mathrm{N}$ ratios as wells as $\delta^{13} \mathrm{C}$ enable differentiation of organic sources.

In the current study, the original set of properties was reduced to a subset of 13 parameters created by removing highly correlated variables, and by retaining only corrected values of the measurements. The environmental variables were normalized by dividing all parameters by their standard deviation by log-transforming all percentage values (Appendix B.7). The RDA was conducted using a matrix containing these normalized values and the reduced set of 33 MOTUs/MOTU groups described above (Appendix B.6).

\section{Results}

\subsection{Vascular plants}

In vascular plant dataset 1 (vp1) and dataset 2 (vp2), a total of 169,192 and 172,029 sequence reads could be assigned to samples, resulting in 1188 and 854 unique sequences fitting the length and count thresholds, respectively (Appendix A.1). Further filtering, cleaning, taxonomic annotation and discarding sequences identical to cultivated plants resulted in a total of 17 MOTUs ( 9 from vp1 and 16 from vp2) regarded as reliably authentic (Fig. 2, Appendix B.1). Seven MOTUs were identified to the species level and six MOTUs to the genus level (Luzula represented by two MOTUs). One MOTU was identified as either Calamagrostis or Agrostis, two to the family level (Asteraceae, Ranunculaceae), and one to the tribe level (Gnaphalieae; most likely representing Antennaria). Reliably authentic sequences were retrieved from 17 of the 20 samples, representing all three zones (Fig. 2). The most commonly retrieved genera were Saxifraga, Salix and Poa, each occurring in eight samples.

In addition to the reliably authentic sequences, we recovered sequences that we considered to be of uncertain authenticity, including likely contaminants. These sequences, together with the specific reasons for excluding each of them, are listed in Appendix B.5. In this respect, the identifications based on the EMBL-derived reference library were particularly valuable, as several food plants and other common contaminants could only be identified using the EMBL library (e.g., one sequence had a best identity value of 0.96 to 


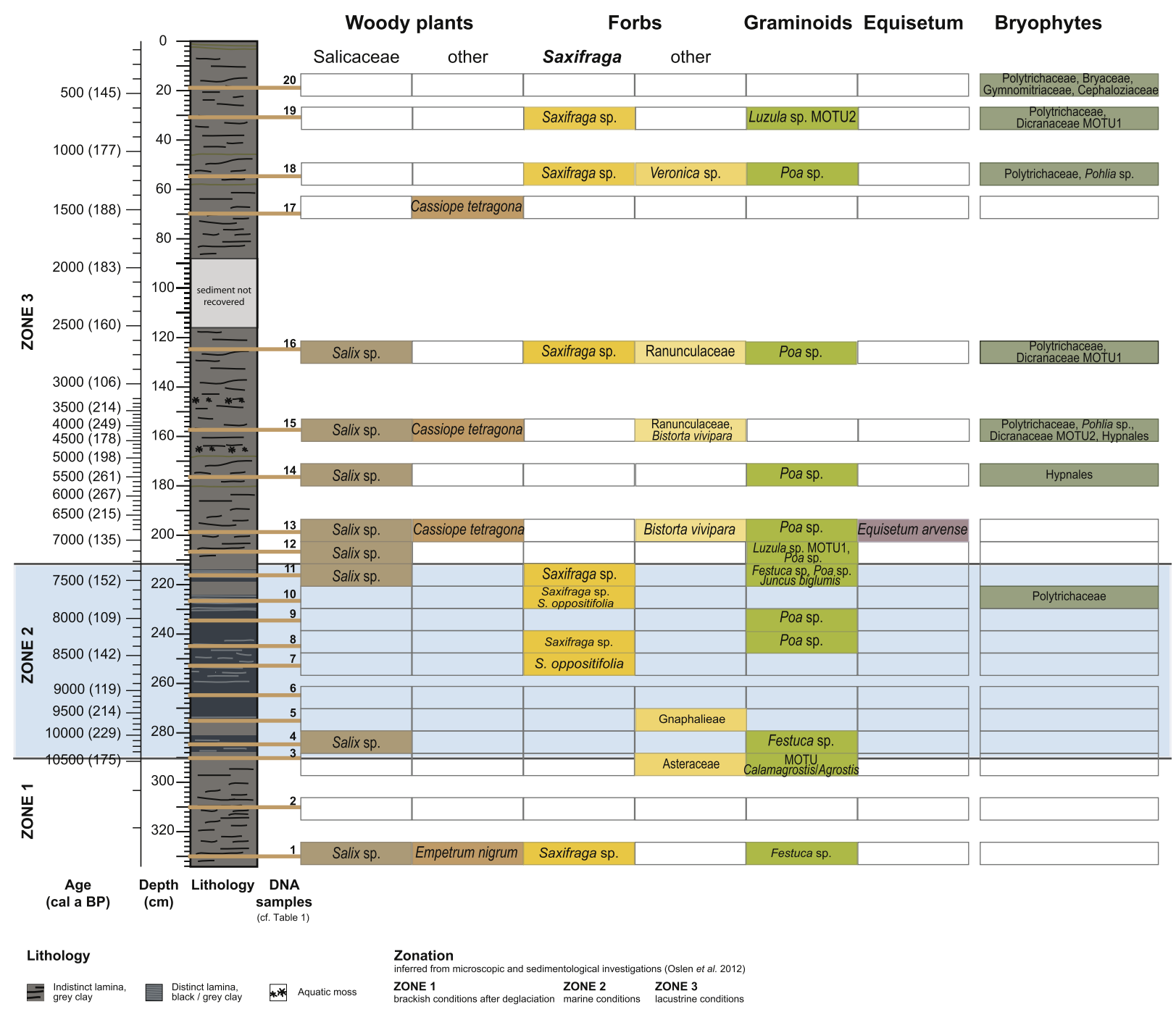

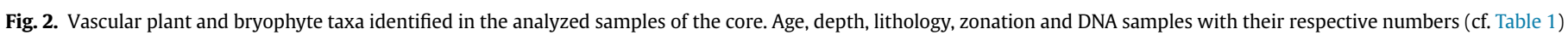
are shown, with details on lithology and zonation explained in the figure. The displayed zonation follows that inferred by Olsen et al. (2012).

Larix sp. in the arctic library, but it had a best identity value of 1 to Cedrus sp. in the EMBL library; Cedrus is highly unlikely to have occurred at any time in North Greenland, and the sequence was removed.) All sequences that were identified in the blanks were removed from the dataset (e.g., Pinus sp. was retrieved from the extraction blank in both sequencing runs).

The oldest sample in the record, dated to ca 10,800 cal yr BP, yielded Empetrum nigrum, Saxifraga sp., Festuca sp. and Salix sp. (the latter identified in vp1 with low read numbers). No authenticated sequences of vascular plants were found in the sample above, while Asteraceae and Calamagrostis/Agrostis were retrieved at the border between zones 1 and 2 .

The lowermost sample of marine zone 2 (age ca 10,300 cal yr BP) contained Festuca sp. and Salix sp. The most common genus found in this part of the core was Saxifraga, occurring from about 8600 cal yr BP onward. Different sequences identified as Saxifraga were retrieved, of which one was assigned to Saxifraga oppositifolia, the currently most common Saxifraga species in the area according to our observations. Other taxa recovered from zone 2 were Gnaphalieae, Poa sp., Festuca sp. and Juncus biglumis.

Salix appeared before the transition to zone 3 and was continuously present from about 7400 to 2750 cal yr BP. Cassiope tetragona was retrieved from three samples in zone 3 (ca 6900, 4250, and 1500 cal yr BP). Herbaceous taxa retrieved in zone 3 were Saxifraga sp., Bistorta vivipara, Gnaphalieae, Ranunculaceae and Veronica sp. Graminoids were represented by Poa sp. and by the two Luzula MOTUs, and one sample contained Equisetum arvense.

\subsection{Bryophytes}

Bryophyte sequences were obtained from seven samples, both from PCRs with bryophyte specific primers and from the PCRs targeting vascular plants (Fig. 2). From the sequencing of bryophyte specific PCR products a total of 857 sequences could be assigned to samples, corresponding to 51 unique sequences fitting the length and count thresholds. The vascular plant PCRs yielded a total of 7328 bryophyte sequences retained after filtering and taxonomic annotation. The combined dataset resulted in eight bryophyte MOTUs (Appendix B.2). One was identified to a genus, six to families and one to an order.

The most commonly identified taxon was Polytrichaceae, retrieved from five samples in zone 1 and one sample in zone 2, with the earliest find at about 7750 cal yr BP. It was the only bryophyte retrieved from a sample older than 5500 cal yr BP. In samples of this age and younger, bryophytes were retrieved from six of the seven samples. Other identified taxa were Hypnales, 
Dicranaceae (with two MOTUs), Bryaceae, Gymnomitriaceae, Cephaloziaceae and Pohlia sp.

\subsection{Diatoms and other algae}

\subsubsection{Taxonomic characterization}

The reactions with primers designed to be specific for diatoms were positive in 18 samples, yielding 454,878 sequences assigned to samples, with 1166 unique sequence types after filtering for length and sequence count thresholds, and a total of 176 MOTUs were retained after further filtering. Of these, 68 MOTUs had a best identity value of 0.95 or more in the ecotag analysis and were therefore taxonomically annotated. The remaining 108 MOTUs were named with numbers (MOTU69 - MOTU176). Although not being taxonomically annotated by the ecoTag analysis, they were included in the statistical analyses and the higher-level taxonomic positions of their best BLAST hits were recorded (Appendix B.3, Fig. 3). All sequences were inferred to originate from algae, and most (77\%) had closest affinities to diatoms. Other groups represented in the sequences were Phaeophyceae (brown algae, 9.7\%), Dictyochophyceae (silicoflagellates,
6.3\%) and Eustigmatophyceae (4\%). The remaining sequences $(<3 \%)$ had closest hits in Chrysophyceae, Phaeothamniophyceae and Rhodophyta.

The 68 sequence types that were taxonomically annotated with ecotag were identified to 31 different taxa at different taxonomic levels (Appendix B.3). Of these, 21 sequence types (31\%) were identified to species level, resulting in 11 different species; 29 sequence types (43\%) were identified to genus level, placed in 12 different genera; and the remaining sequence types (26\%) were identified to higher taxonomic levels. All three major classes of diatoms (Round et al., 1990), the raphid pennates (Bacillariophyceae), centrics (Coscinodiscophyceae) and araphid pennates (Fragilariophyceae), were represented (Fig. 3). The most commonly identified diatom was Pseudo-nitzschia sp., found in four samples, followed by Chaetoceros socialis and Thalassiosira sp., both found in three samples. Other genera and species that were identified were only found in one or two samples each. Apart from diatoms (45 MOTUs), the taxonomically annotated sequences contained Phaeophyceae (brown algae) and the genus Nannochloropsis (Eustigmatophyceae).

The richness of sequence types and the diversity of diatoms retrieved per sample varied strongly through the core. The oldest

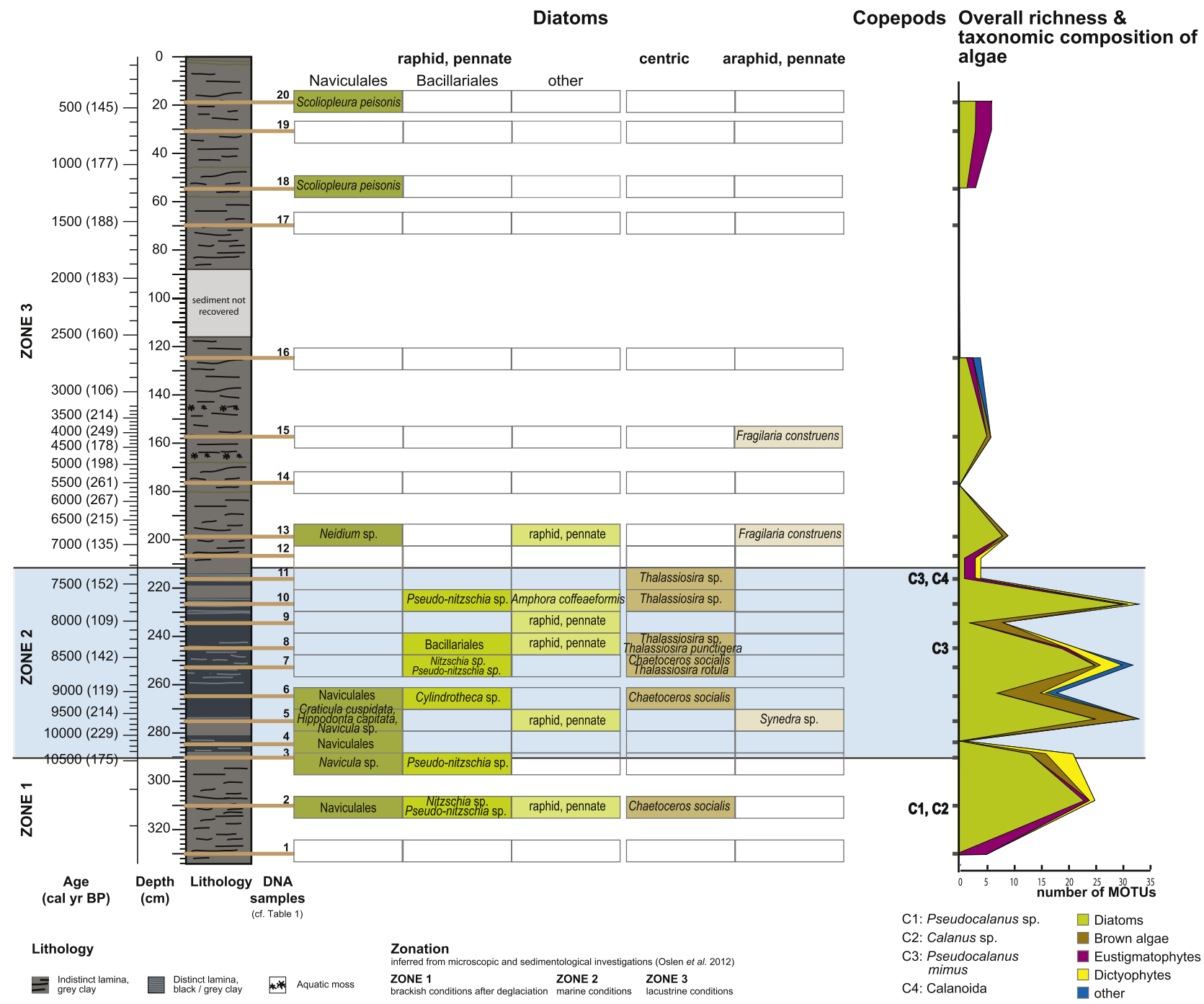

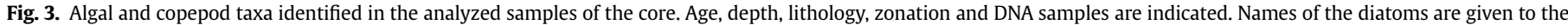

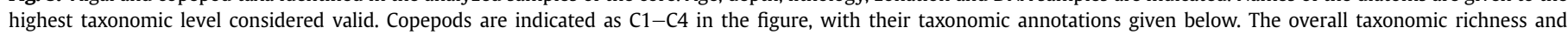
taxonomic composition (far right panel) is based on the higher-level annotation of all identified MOTUs. 
sample contained only sequences identified as Nannochloropsis sp. and no diatom sequences (Fig. 3). The number of sequences and the percentage of diatoms were remarkably higher in the sample above. Highest numbers were reached in zone 2 of the core, where samples contained up to 34 sequence types. This part of the core also contained most of the taxonomically annotated diatom sequences and most of the brown algae sequences. Samples from zone 3 had a considerably lower richness, with a maximum of five sequence types reached at depth 198-199 cm ( 6900 cal yr BP). The percentage of diatom sequences was also lower towards the top of the core, and, similar to the oldest sample, a relatively high percentage of sequences were identified as Nannochloropsis sp.

\subsubsection{Statistical analyzes of the algal MOTU matrix and environmental variables}

In the final PCA of 33 MOTUs/MOTU groups from 18 samples (Fig. 4a, overlaid ordination of MOTUs/MOTU groups and samples, Appendix C.2), samples with formerly inferred lacustrine conditions (zone 3, cf. Olsen et al., 2012) were clearly distinct from most samples of the brackish and marine zones along axis 1. Samples from zone 1 , formerly inferred as brackish, did not cluster separately, but were split between those with marine and freshwater conditions. The highest loadings on axis 1 (18.82\% of the total variance) were obtained by MOTU158, MOTU82 and Pseudo-nitzschia sp., only retrieved from brackish and marine zones. MOTU group 10 and the freshwater taxa Scoliopleura peisonis and Nannochloropsis, obtained the lowest axis 1 loadings. Axis 2 (11.45\%) separated the brown algae Battersia arctica, Desmarestia sp. and MOTU group 16 (containing another Battersia arctica sequence and Chaetopteris plumosa) from Nannochloropsis, and also separated samples with Battersia arctica from those with Nannochloropsis.

The RDA including 33 MOTUs/MOTU groups along with the 13 environmental variables (Fig. 4b, Appendix C.3) revealed correlations between the presence of certain diatom taxa and chemical and physical properties of the sediments. The environmental variables had the highest factor loadings and contributed substantially to the samples' grouping. Combined, axis 1 and 2 separated three groups of samples, distinctly clustering with environmental variables: the freshwater samples and two groups of marine samples, while the samples from the brackish zone 1 again plotted within these groups. Highest loadings along axis 1 (22.5\%) were obtained by $\mathrm{Br} / \mathrm{C}$ (bromium to organic carbon ratio, correlated with salinity), $\delta^{13} \mathrm{C}$, and Ca, and by the marine diatom Pseudo-nitzschia, unclassified Bacillariaceae and the brown algae Battersia arctica. The freshwater diatom Scoliopleura peisonis and Nannochloropsis had the lowest loadings. Axis $2(12.4 \%)$ separated the two marine taxa Pseudo-nitzschia sp. and Desmarestia sp..

\subsection{Copepods}

Copepod-specific reactions resulted in three positive PCR products, all from the marine/brackish zones 1 and 2, which yielded 171,987 sequence reads assigned to samples. These corresponded to 669 unique sequence types fitting the length and count thresholds, and to eight sequence types after filtering with obiclean, all identified as marine taxa. The sample from the brackish zone 1 ( 10,650 cal yr BP) yielded sequences identified as Pseudocalanus sp. and Calanus sp., while the sequences from samples of the marine zone 2 (at $\sim 8300 \mathrm{cal}$ yr BP and $\sim 7400$ cal yr BP) were identified as Pseudocalanus mimus and Calanoida (Appendix B.4, Fig. 3).

\section{Discussion}

\subsection{Stratigraphic integrity of the DNA record}

We found the distribution of the DNA of aquatic organisms in the core to be consistent with the delimitation of marine and nonmarine phases (Olsen et al., 2012). We consider this finding to strongly indicate that leaching of DNA or other disturbance do not pose a problem in the Bliss Lake DNA record, a necessary prerequisite for further paleoecological inference. In particular, we identified the presence of either marine or freshwater algal groups in the sediment samples, and it was possible to infer shifts in the paleocommunity composition over time. The separation of PCA clusters based on the taxonomic diversity of the recovered DNA sequences (Fig. 4a) is consistent with the zonation inferred from the microscopic analyses of diatom valves (Olsen et al., 2012). Furthermore, the direct comparison of organismal remains identified by visual inspection by Olsen et al. (2012) with our DNA record
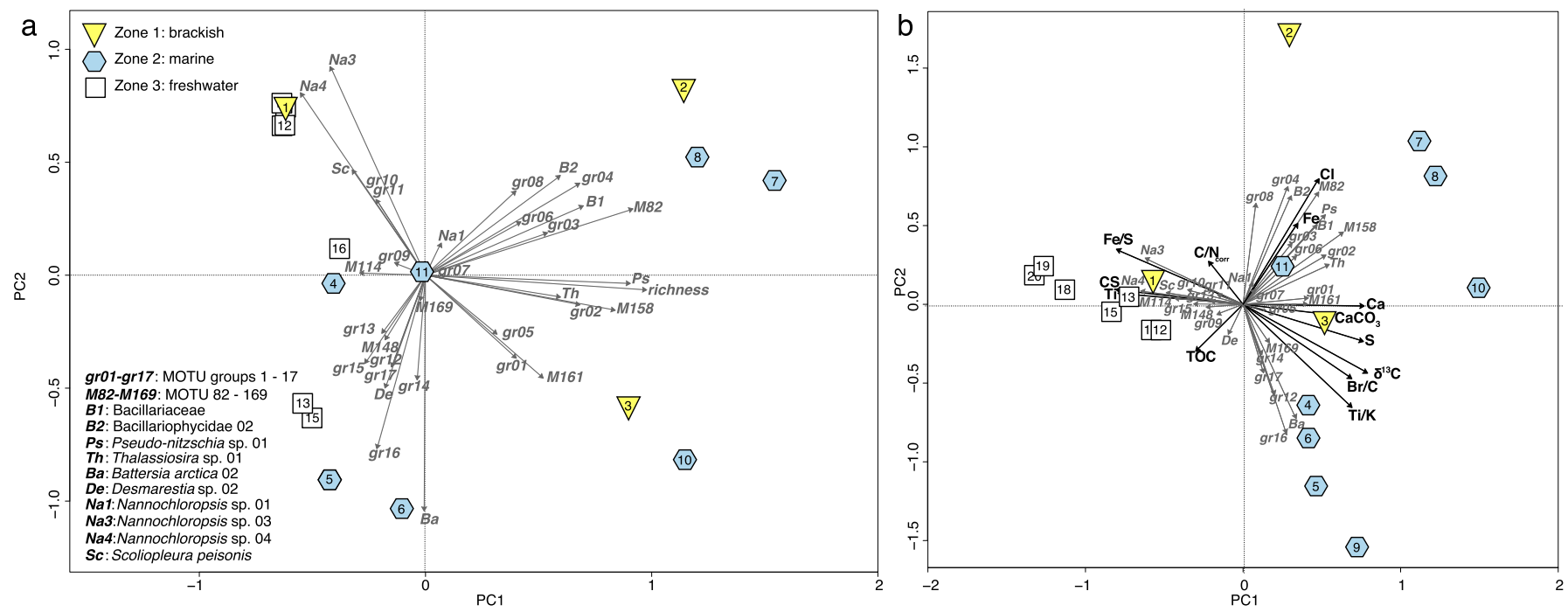

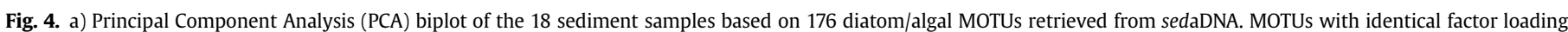

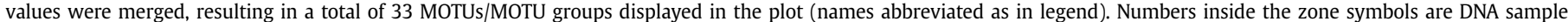

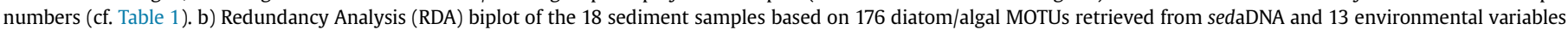
describing physical, chemical and geological properties of the sediments. 
confirms the stratigraphic integrity of the record. For example, the aquatic moss Warnstorfia exannulata (Schimp.) Loeske was identified at depths of $145 \mathrm{~cm}$ and $164 \mathrm{~cm}$ (Olsen et al., 2012), and the DNA samples taken close to these depths (157 and $176 \mathrm{~cm}$ ) contain a sequence identified to the order Hypnales, to which W. exannulata belongs. Finally, there is an interesting correspondence between the morphological record and the DNA record, which contradicts the inferred overall zonation, but is consistent between the two records: The microscopic record of diatom valves in the lacustrine zone 3 contained some polyhalobous taxa, which were interpreted as allochthonous, marine input by Olsen et al. (2012), and which showed a peak at 157 and $193 \mathrm{~cm}$. Similarly, the DNA record contains sequences of brown algae, a strictly marine group, at 157 and $198 \mathrm{~cm}$ (Fig. 3). This points to some marine input in these particular samples, which were taken from the otherwise lacustrine zone 3 . In effect, the correspondence between the two records provides additional support for the stratigraphic integrity of the DNA.

The apparent absence of leaching is in accordance with most analyzed DNA records, including subaquatically deposited (e.g. Epp et al., 2010; Coolen et al., 2013), permanently frozen (e.g. Willerslev et al., 2003) or non-frozen soils and sediments (Hebsgaard et al., 2009), but a notable exception to this pattern has been observed in temperate sediments from New Zealand (Haile et al., 2007).

\subsection{DNA-based paleoenvironmental history of Bliss Lake and surroundings}

Using sedimentary ancient DNA, we were able to identify organisms from several different taxonomic groups and trace their occurrence in Bliss Lake and its surroundings since the deglaciation of northernmost Greenland. Our record shows early appearances of vascular plants and an open fell-field vegetation throughout the Holocene, and distinct historical salinity changes in the lake water are reflected in the DNA of algae and copepods.

The DNA record of vascular plants starts at approximately 10,800 cal yr BP (depth $331 \mathrm{~cm}$ ) with four taxa: Empetrum nigrum, Saxifraga sp., Festuca sp. and Salix sp. (albeit with low number of reads). Empetrum nigrum has repeatedly been recorded as the earliest woody plant in Greenland, with the oldest record from Scoresbysund in East Greenland $\left(70^{\circ} 30^{\prime} \mathrm{N}, 21^{\circ} 58^{\prime} \mathrm{W}\right)$, where its heavy, short-dispersed pollen tetrads are present in the oldest Holocene lake cores that date back to at least 11,000 cal yr BP (Funder, 1978). Macro remains further north in East Greenland, to the north of its present distribution area, date to ca 10,400 cal yr BP (Bennike et al., 1999; Wagner et al., 2008). The early appearance of E. nigrum has been attributed to rapid endozoic transport of the fruit stone by birds, and this might also explain its early appearance in the Bliss Lake record. Modern DNA data have shown that this species has extreme long-distance dispersal ability, with recent dispersal at the full northern circumpolar as well as at the bipolar scale (Popp et al., 2011).

The retrieval of plant DNA in the oldest sample, including E. nigrum, which presently has its northern limit several hundred kilometers to the south (Bay, 1992), indicates relatively high summer temperatures that could enable growth of bryophytes and vascular plants around the lake already in the early Holocene. Plant growth may however have been marginal and unstable. The low amount of plant DNA we retrieved in the samples directly above the oldest sample could be caused by deteriorating conditions for the sedimentation (and hence preservation) of plant DNA, but it could also reflect that the earliest Holocene plant arrival did not result in long-lasting establishment. Molecular genetic structure of modern plant populations in the Arctic indicates that their current distribution is more limited by establishment success than by dispersal potential (Alsos et al., 2007).

The occurrence of Salix sp. in the samples dating to $~ 10,300$ and $\sim 10,800$ cal yr BP is somewhat surprising and should be interpreted with caution. The only Salix species present in the area today, and the only species that has previously been identified in macrofossil records from north Greenland, is S. arctica. Most records from northern and northeastern Greenland detect $S$. arctica only from about 8000-7500 years onward (Fredskild, 1985; Blake et al., 1992; Björck et al., 1994). Its earliest Holocene record from Greenland is from Nioghalvfjerdsfjorden, about $450 \mathrm{~km}$ southeast of Bliss Lake, dated to approximately 8800 cal yr BP (Bennike and Weidick, 2001). This has been considered a minimal date of its arrival, and its route of immigration is suggested to have been from northern Canada. The area around Bliss Lake is situated along the proposed immigration route, but the sequence data move the immigration date back by almost 2000 years. However, the number of sequence reads retrieved in these samples is very low, and much lower than in the samples from 7400 cal yr BP onwards (Appendix B.1). The early occurrence could therefore be interpreted as an artifact of the sequencing procedure (i.e. tag switching, Carlsen et al., 2012), cross-contamination or other laboratory contamination (Willerslev et al., 2014; K. Andersen, pers. comm.). Nevertheless, the early Salix sp. sequences may be authentic, and this finding warrants further investigation.

The pattern of initial high diversity and rapid decline in vascular plant DNA at the bottom of the core is remarkably different from that observed for the algal DNA. The oldest sample contains only sequence types identified as Nannochloropsis, and no diatom DNA. The diversity of algal DNA sequence types increased drastically from the oldest sample to the sample above (Fig. 3, Appendix B.3) and remained high throughout most of zones 1 and 2. This could reflect either better conditions for diatom growth as nutrient availability increased, or improved conditions for diatom DNA preservation under more saline conditions. The increase in algal DNA sequence types occurs in parallel to increasing marine influence documented by abiotic parameters during zone 1 (Olsen et al., 2012). Overall, the algal DNA sequence composition recovers the environmental changes previously inferred by Olsen et al. (2012). Both the change to full marine conditions at $\sim 10,500$ cal yr BP, as well as the transition to a lacustrine environment at $\sim 7200$ cal yr BP, are reflected in the results of the PCA ordination (Fig. 4).

The change to marine conditions did not seem to influence the deposition of vascular plant DNA, as its recovery and diversity did not notably differ from the other phases of the lake. During the marine phase of the lake's history, it was likely a shallow marine bay, with a vascular plant DNA input originating from a catchment that was similar to the catchment during the other phases. The record largely reflects polar desert conditions around the lake with sequences identified as Saxifraga oppostifolia, Saxifraga sp., Poa sp. and J. biglumis. It also contains Festuca sp., one sequence identified as Gnaphalieae, and the second of the early Salix appearances discussed above. The youngest sample of the marine phase records the start of continuous presence of Salix sp., in agreement with previous records of the establishment of $S$. arctica in North and Northeast Greenland (Funder and Abrahamsen, 1988; Bennike, 1999; Wagner et al., 2008). It is detected until about 2750 cal yr $\mathrm{BP}$ as a component of an open vegetation containing plants such as Bistorta vivipara, Ranunculaceae, Saxifraga sp., Cassiope tetragona, Poa sp., Luzula sp. and E. arvense. This indicates that Salix remained present in the lake's catchment during a time period of cooling and increase of sea ice at the adjacent coast, beginning ca 6000 cal yr BP (Olsen et al., 2012). The timing of the disappearance of Salix in the lake's drainage area cannot be established more precisely, because the sediments between $116 \mathrm{~cm}$ and $87 \mathrm{~cm}$ 
were not recovered, but this vegetation change occurred later than that documented for another North Greenland lake (Funder and Abrahamsen, 1988), where polar desert developed from sparse high arctic tundra ca 4300 cal yr BP.

The temperatures around Bliss Lake have been inferred to have slightly increased from ca 3300 until 910 cal yr BP (Olsen et al., 2012), and this is supported by our findings of Cassiope tetragona (ca 1500 cal yr BP) and Veronica sp. (ca $1200 \mathrm{cal} \mathrm{yr} \mathrm{BP).} \mathrm{At} \mathrm{around}$ $845 \mathrm{cal}$ yr BP there appears to have been a significant transition to colder conditions. After this time the vascular plant DNA record shows only Saxifraga sp. and Luzula sp., at about 750 cal yr BP, while no putatively authentic DNA was recovered from the topmost sample with an inferred age of about $500 \mathrm{cal}$ yr BP. The complete lack of vascular plant DNA at the top of the core is likely due to the year-round ice cover that was noted during core sampling. This ice cover has remained despite proxies indicating increasing temperatures from about 510 cal yr BP (Olsen et al., 2012).

The record of algal DNA in the lacustrine part of the Bliss Lake core contains only a few different sequence types, especially of diatoms, and for most of these sequence types accurate taxonomic assignment was not possible. Interestingly, a sequence type identified as Fragilaria sp. appeared in the lower lacustrine part of the core, which may stem from the microscopically identified Fragilaria pinnata, which is commonly found in lakes after isolation from the sea (Olsen et al., 2012). The other more precisely identified diatoms, Neidium sp. and Scoliopleura peisonis, confirm the freshwater conditions during this phase. The low richness in algal DNA could be linked to poor preservation of diatom DNA, but it is also consistent with the low nutrient availability inferred for this phase of the lake's history (Olsen et al., 2012).

\subsection{Multi-taxon sedaDNA metabarcoding for paleoecological inference in low productivity environments}

The Bliss Lake sediment core, for which substantial paleoecological changes had previously been inferred (Olsen et al., 2012), offered a unique opportunity to test the feasibility and validity of DNA-based multi-taxon inference in an extreme environment such as the High Arctic. The few lake sediment DNA studies carried out to date have focused mostly on vascular plants (Parducci et al., 2012, 2013; Pedersen et al., 2013; Boessenkool et al., 2014; Willerslev et al., 2014), but lake sediments contain DNA from many different organism groups. This enables multiproxy studies, which can more confidently infer paleoecological history than studies relying on single proxies (Birks and Birks, 2006). Importantly, the results of our multi-taxon DNA analysis of the Bliss Lake core are in agreement with previously inferred ecological changes, as shown by the statistical analyses of the algal sequences (Fig. 4) and by the identification of marine copepods only in phases with elevated levels of salinity. This confirms the suitability of multi-taxon DNA approaches for paleoecological inferences, even in extreme low-productivity settings such as the High Arctic. Here, low DNA concentrations and variable detection success for targeted taxa pose a limitation to the multi-taxon metabarcoding approach. Relatively continuous records throughout the core were achieved only with the primers targeting diatoms (18 positive samples) and vascular plants (17 positive samples). Nevertheless, by including multiple taxa, paleoecological inferences drawn from dominant organisms can be obtained, and DNA data can complement existing paleorecords.

The clearest signal of paleoecological change was recovered using a diatom specific reaction. Diatoms are a classical proxy for the paleoecological analyses of lake ecosystems (Douglas and
Smol, 1999), and diatom DNA has previously been retrieved from lake sediments (Coolen et al., 2004; Epp et al., 2011; StoofLeichsenring et al., 2012). Here we used a group-specific metabarcoding approach including high-throughput amplicon sequencing and retrieved a high number of sequence types of a fragment of the $r b c L$ gene. A difficulty encountered using this approach was the taxonomic assignment of the retrieved sequences: most sequences could not be taxonomically assigned using our strict criteria, likely due to the current lack of adequate reference libraries (Kermarrec et al., 2013). Therefore, classical inference of ecological conditions from diatom data was limited in our study. Nevertheless, it was possible to identify presence of either marine or freshwater groups in sediment samples, and to infer shifts in the paleocommunity composition over time. We have thus shown that the analysis of algal DNA can be used as an indicator for environmental conditions, and this approach may reach its full potential when more complete reference libraries have been developed.

With a few exceptions, the richness in the algal DNA record and the percentage of diatom sequences retrieved were particularly high in periods with elevated salinity. This indicates that conditions were good for diatom growth, but the high numbers could also reflect that DNA degradation is delayed under saline conditions (Lindahl, 1993) and that marine sediments might be particularly ideal for sedimentary ancient DNA analyses. The freshwater samples, on the other hand, displayed much lower sequence diversity, and in some samples the PCR product was largely dominated by sequences identified to the non-diatom genus Nannochloropsis (eustigmatophytes). The appearance of the non-target Nannochloropsis DNA is putatively an indication of very low diatom DNA concentrations.

For copepods, our finding represents the second Holocene paleorecord from Greenland to date. The only other published record is copepod egg sacs from a single lake, tentatively identified as Diaptomus castor (Bennike, 1998), a species that lives in shallow ponds (Bennike et al., 2000). The overall poor detection success we obtained for copepod DNA is possibly due to the relatively long fragment ( $300 \mathrm{bp})$ amplified by the currently available primers (Bissett et al., 2005). They have successfully been used in previous studies (Xu et al., 2011; Coolen et al., 2013), but the fragment length is beyond the limit of degradation for many ancient DNA samples (Pääbo et al., 2004; Binladen et al., 2007; Rasmussen et al., 2010). Development of a shorter marker could enhance the use of copepod DNA in paleoecology.

The lack of bryophytes from the older samples and the generally poor retrieval of bryophytes are unexpected, as bryophytes are both species-rich and important biomass producers in High Arctic vegetation (Hassel et al., 2012, 2014). Both leaves and shoot fragments can be successfully conserved in old lake sediments (e.g. Vorren et al., 2013). However, detection of ancient bryophyte DNA has been reported to be difficult in previous studies (Suyama et al., 2008; Epp et al., 2012), and the late start of bryophyte DNA detection (at $225 \mathrm{~cm}$ ) in our core is in line with this. This sample is nearly 8000 cal yr BP old, but we would have expected bryophytes to be present earlier in the record. The apparently low preservation potential of bryophyte DNA could be linked to the high production of secondary metabolites in bryophytes (Xie and Lou, 2009), which enhance DNA degradation. Vascular plant DNA on the other hand was found down to the bottom of the core, albeit with low diversity. Limited diversity in vascular plant DNA in comparison to pollen has previously been found in other lake sediment records (Jørgensen et al., 2012; Parducci et al., 2013; Boessenkool et al., 2014). In the case of Bliss Lake, however, the vegetation is very scarce, and the limited diversity in the DNA record does not stand out from pollen and macrofossil studies 
conducted in the wider area (Funder and Abrahamsen, 1988; Wagner et al., 2008).

\section{Conclusions}

Understanding past dynamics of High Arctic ecosystems is of high relevance with regard to current global change, but paleoecological studies are challenging in this low productivity environment. Using ancient DNA from a lake sediment core, we were able to analyze vascular plants, bryophytes, diatoms and other algae, and copepods throughout the Holocene in northernmost Greenland. Both the plant and algal DNA records indicate relatively high summer temperatures in the early Holocene, with several identified plant taxa being present shortly after deglaciation, including the woody plant Empetrum nigrum. The remaining record of plant sedaDNA corresponds well with current knowledge of the vegetation history in North Greenland. Our analysis of algal DNA traced changes between marine and lacustrine phases in the lake's history, echoing previous inferences based on microscopic diatom investigations. Our detection success differed markedly between the organism groups investigated, but the sedaDNA record yielded novel paleoecological data for all analyzed groups and thus proved to be a valuable tool in low productivity ecosystems such as the High Arctic.

\section{Acknowledgments}

This work is part of the BarFrost project supported by the Research Council of Norway (grant no. 191627/V40 to CB). The Bliss Lake fieldwork was made possible by a grant to SF from the Danish Research Council (FNU 272-05-0398). We thank Eric Coissac and Lucie Zinger for assistance in the analyses of the sequence data, helpful discussions and comments on the manuscript, and one reviewer for constructive comments.

\section{Appendix A. Supplementary data}

Supplementary data related to this article can be found at http:// dx.doi.org/10.1016/j.quascirev.2015.03.027.

\section{References}

ACIA, 2005. Impacts of a Warming Arctic: Arctic Climate Impact Assessment Cambridge University Press, Cambridge, UK.

Alsos, I.G., Eidesen, P.B., Ehrich, D., Skrede, I., Westergaard, K., Jacobsen, G.H., Landvik, J.Y., Taberlet, P., Brochmann, C., 2007. Frequent long-distance plant colonization in the changing Arctic. Science 316, 1606-1609.

Altschul, S.F., Madden, T.L., Schaffer, A.A., Zhang, J.H., Zhang, Z., Miller, W., Lipman, D.J., 1997. Gapped BLAST and PSI-BLAST: a new generation of protein database search programs. Nucleic Acids Res. 25, 3389-3402.

Bay, C., 1992. A phytogeographical study of the vascular plants of northern Greenland - north of $74^{\circ}$ northern latitude. In: Meddelelser om Grønland, Bioscience, p. 102.

Bennike, O., 1998. Fossil egg sacs of Diaptomus (Crustaceae: Copepoda) in Late Quaternary lake sediments. J. Paleolimnol. 19, 77-79.

Bennike, O., 1999. Colonisation of Greenland by plants and animals after the last ice age: a review. Polar Rec. 35, 323-336.

Bennike, O., Weidick, A., 2001. Late quaternary history around Nioghalvfjerdsfjorden and Jokelbugten, North-East Greenland. Boreas 30, 205-227.

Bennike, O., Björck, S., Bocher, J., Hansen, L., Heinemeier, J., Wohlfarth, B., 1999. Early Holocene plant and animal remains from North-east Greenland. J. Biogeogr. 26, 667-677.

Bennike, O., Björck, S., Böcher, J., Walker, I.R., 2000. The quaternary arthropod fauna of Greenland: a review with new data. Bull. Geol. Soc. Den. 47, 111-134.

Binladen, J., Gilbert, M.T.P., Bollback, J.P., Panitz, F., Bendixen, C., Nielsen, R., Willerslev, E., 2007. The use of coded PCR primers enables high-throughput sequencing of multiple homolog amplification products by 454 parallel sequencing. PLoS One 2.

Birks, H.H., Birks, H.J.B., 2006. Multi-proxy studies in palaeolimnology. Veg. Hist. Archaeobotany 15, 235-251.
Bissett, A., Gibson, J.A.E., Jarman, S.N., Swadling, K.M., Cromer, L., 2005. Isolation, amplification, and identification of ancient copepod DNA from lake sediments. Limnol. Oceanogr. 3, 533-542.

Björck, S., Wohlfarth, B., Bennike, O., Hjort, C., Persson, T., 1994. Revision of the early Holocene lake sediment based chronology and event stratigraphy on Hochstetter Forland, NE Greenland. Boreas 23, 513-523.

Blake Jr., W., Boucherle, M.M., Fredskild, B., Janssens, J.A., Smol, J.P., 1992. The geomorphological setting, glacial history and holocene development of 'Kap Inglefield SB', Inglefield land, North-West Greenland. Meddelelser Om. Gronlund, Geosci. 27, 42.

Boessenkool, S., McGlynn, G., Epp, L.S., Taylor, D., Pimentel, M., Gizaw, A., Nemomissa, S., Brochmann, C., Popp, M., 2014. Use of ancient sedimentary DNA as a novel conservation tool for high-altitude tropical biodiversity. Conserv. Biol. $28,446-455$

Brochmann, C., Gabrielsen, T.M., Nordal, I., Landvik, J.Y., Elven, R., 2003. Glacial survival or tabula rasa? The history of North Atlantic biota revisited. Taxon 52, $417-450$.

Callaghan, T.V., Bjorn, L.O., Chernov, Y., Chapin, T., Christensen, T.R., Huntley, B. Ims, R.A., Johansson, M., Jolly, D., Jonasson, S., Matveyeva, N., Panikov, N. Oechel, W., Shaver, G., Elster, J., Henttonen, H., Laine, K., Taulavuori, K., Taulavuori, E., Zockler, C., 2004. Biodiversity, distributions and adaptations of arctic species in the context of environmental change. Ambio 33, 404-417.

Cappelen, J., Jensen, J.J., 2001. Jordens Klima - Guide Til Vejr Og Klima I 156 Lande. Danmarks Meteorologiske Institut. Teknisk Rapport (Online) 01-17. http:// www.dmi.dk/f+u/publikation/tekrap/tekniskerap.html.

Carlsen, T., Aas, A.B., Lindner, D., Vralstad, T., Schumacher, T., Kauserud, H., 2012. Don't make a mista(g)ke: is tag switching an overlooked source of error in amplicon pyrosequencing studies? Fungal Ecol. 5, 747-749.

Champlot, S., Berthelot, C., Pruvost, M., Bennett, E.A., Grange, T., Geigl, E.M., 2010. An efficient multistrategy DNA decontamination procedure of PCR reagents for hypersensitive PCR applications. PLoS One 5.

Coolen, M.J.L., Muyzer, G., Rijpstra, W.I.C., Schouten, S., Volkman, J.K., Damste, J.S.S. 2004. Combined DNA and lipid analyses of sediments reveal changes in Holocene haptophyte and diatom populations in an Antarctic lake. Earth Planet. Sci. Lett. 223, 225-239.

Coolen, M.J.L., Orsi, W.D., Balkema, C., Quince, C., Harris, K., Sylva, S.P., FilipovaMarinova, M., Giosan, L., 2013. Evolution of the plankton paleome in the Black Sea from the Deglacial to Anthropocene. Proc. Natl. Acad. Sci. U. S. A. 110, 8609-8614.

Cremer, H., Bennike, O., Wagner, B., 2008. Lake sediment evidence for the last deglaciation of eastern Greenland. Quat. Sci. Rev. 27, 312-319.

Douglas, M.S.V., Smol, J.P., 1999. Freshwater diatoms as indicators of environmental change in the high Arctic. In: Stoermer, E.F., Smol, J.P. (Eds.), The Diatoms: Applications for the Environmental and Earth Sciences. Cambridge University Press, Cambridge, pp. 227-244.

Eidesen, P.B., Ehrich, D., Bakkestuen, V., Alsos, I.G., Gilg, O., Taberlet, P., Brochmann, C., 2013. Genetic roadmap of the Arctic: plant dispersal highways, traffic barriers and capitals of diversity. New. Phytol. 200, 898-910.

Elven, R., Murray, D.F., Razzhivin, V.Y., Yurtsev, B.A., 2011. Annotated Checklist of the Panarctic Flora (PAF). Natural History Museum, University of Oslo.

Epp, L.S., Stoof, K.R., Trauth, M.H., Tiedemann, R., 2010. Historical genetics on a sediment core from a Kenyan lake: intraspecific genotype turnover in a tropical rotifer is related to past environmental changes. J. Paleolimnol. 43, 939-954.

Epp, L.S., Stoof-Leichsenring, K.R., Trauth, M.H., Tiedemann, R., 2011. Molecular profiling of diatom assemblages in tropical lake sediments using taxon-specific PCR and Denaturing High-Performance Liquid Chromatography (PCR-DHPLC). Mol. Ecol. Resour. 11, 842-853.

Epp, L.S., Boessenkool, S., Bellemain, E.P., Haile, J., Esposito, A., Riaz, T., Erséus, C., Gusarov, V., Edwards, M.E., Johnsen, A., Stenøien, H.K., Hassel, K., Kauserud, H., Yoccoz, N.G., Bråthen, K.A., Willerslev, E., Taberlet, P., Coissac, E., Brochmann, C. 2012. New environmental metabarcodes for analysing soil DNA: potential for studying past and present ecosystems. Mol. Ecol. 21, 1821-1833.

Ficetola, G.F., Coissac, E., Zundel, S., Riaz, T., Shehzad, W., Bessiere, J., Taberlet, P., Pompanon, F., 2010. An In silico approach for the evaluation of DNA barcodes. BMC Genomics 11, 434.

Floyd, R., Abebe, E., Papert, A., Blaxter, M., 2002. Molecular barcodes for soil nematode identification. Mol. Ecol. 11, 839-850.

Fredskild, B., 1985. The holocene vegetational development of Tugtuligssuaq and Qeqertat, northwest Greenland. Meddelelser Om. Gronl. Geosci. 14, 1-20.

Funder, S., 1978. Holocene Stratigraphy and Vegetation History in the Scoresby Sund Area, East Greenland.

Funder, S., Abrahamsen, N., 1988. Palynology in a polar desert, Eastern North Greenland. Boreas 17, 195-207.

Funder, S., Goosse, H., Jepsen, H., Kaas, E., Kjær, K.H., Korsgaard, N.J., Larsen, N.K. Linderson, H., Lysa, A., Möller, P., Olsen, J., Willerslev, E., 2011. A 10,000-Year record of arctic ocean sea-ice variability-view from the beach. Science 333, $747-750$

Giguet-Covex, C., Pansu, J., Arnaud, F., Rey, P.J., Griggo, C., Gielly, L., Domaizon, I., Coissac, E., David, F., Choler, P., Poulenard, J., Taberlet, P., 2014. Long livestock farming history and human landscape shaping revealed by lake sediment DNA. Nat. Commun. 5, 3211.

Haile, J., Holdaway, R., Oliver, K., Bunce, M., Gilbert, M.T.P., Nielsen, R., Munch, K. Ho, S.Y.W., Shapiro, B., Willerslev, E., 2007. Ancient DNA chronology within sediment deposits: are paleobiological reconstructions possible and is DNA leaching a factor? Mol. Biol. Evol. 24, 982-989. 
Haile, J., Froese, D.G., MacPhee, R.D.E., Roberts, R.G., Arnold, L.J., Reyes, A.V., Rasmussen, M., Nielsen, R., Brook, B.W., Robinson, S., Demuro, M., Gilbert, M.T.P., Munch, K., Austin, J.J., Cooper, A., Barnes, I., Moller, P., Willerslev, E., 2009. Ancient DNA reveals late survival of mammoth and horse in interior Alaska. Proc. Natl. Acad. Sci. U. S. A. 106, 22352-22357.

Hassel, K., Prestø, T., Smith, N.M., 2012. Scientific Report. In: . Bryophyte diversity in high and low arctic Greenland. Establishment of permanent monitoring transects and bryophyte and bryophyte mapping in Zackenberg and Kobbefjord 2009-2010. Aarhus University, DCE - Danish Centre for Environment and Energy, p. 42.

Hassel, K., Zechmeister, H., Prestø, T., 2014. Mosses (Bryophyta) and liverworts (Marchantiophyta) of the Zackenberg valley, northeast Greenland. Lindbergia 37, 66-84.

Hebsgaard, M.B., Gilbert, M.T.P., Arneborg, J., Heyn, P., Allentoft, M.E., Bunce, M., Munch, K., Schweger, C., Willerslev, E., 2009. 'The farm beneath the sand' - an archaeological case study on ancient 'dirt' DNA. Antiquity 83, 430-444.

Hewitt, G.M., 2004. Genetic consequences of climatic oscillations in the Quaternary. Philos. Trans. R. Soc. Lond. Ser. B-Biol. Sci. 359, 183-195.

Hofreiter, M., Collins, M., Stewart, J.R., 2012. Ancient biomolecules in quaternary palaeoecology, Quat. Sci. Rev, 33, 1-13.

Jørgensen, T., Haile, J., Möller, P., Andreev, A., Boessenkool, S., Rasmussen, M. Kienast, F., Coissac, E., Taberlet, P., Brochmann, C., Bigelow, N.H., Andersen, K., Orlando, L., Gilbert, M.T.P., Willerslev, E., 2012. A comparative study of ancient sedimentary DNA, pollen and macrofossils from permafrost sediments of northern Siberia reveals long-term vegetational stability. Mol. Ecol. 21, 1989-2003.

Kaufman, D.S., Schneider, D.P., McKay, N.P., Ammann, C.M., Bradley, R.S., Briffa, K.R Miller, G.H., Otto-Bliesner, B.L., Overpeck, J.T., Vinther, B.M., Members ALkP, 2009. Recent warming reverses long-term arctic cooling. Science 325, 1236-1239.

Kermarrec, L., Franc, A., Rimet, F., Chaumeil, P., Humbert, J.F., Bouchez, A., 2013. Next-generation sequencing to inventory taxonomic diversity in eukaryotic communities: a test for freshwater diatoms. Mol. Ecol. Resour. 13, 607-619.

Kienast, F., Wetterich, S., Kuzmina, S., Schirrmeister, L., Andreev, A.A., Tarasov, P., Nazarova, L., Kossler, A., Frolova, L., Kunitsky, V.V., 2011. Paleontological records indicate the occurrence of open woodlands in a dry inland climate at the present-day Arctic coast in western Beringia during the Last Interglacial. Quat Sci. Rev. 30, 2134-2159.

Klein, D.R., Bruun, H.H., Lundgren, R., Philipp, M., 2008. Climate change influences on species interrelationships and distributions in High-Arctic Greenland. Adv. Ecol. Res. 40, 81-100.

Larsen, N.K., Kjær, K.H., Funder, S., Möller, P., van der Meer, J.J.M., Schomacker, A. Linge, H., Darby, D.A., 2010. Late quaternary glaciation history of northernmost Greenland - evidence of shelf-based ice. Quat. Sci. Rev. 29, 3399-3414.

Legendre, P., Gallagher, E.D., 2001. Ecologically meaningful transformations for ordination of species data. Oecologia 129, 271-280.

Lindahl, T., 1993. Instability and decay of the primary structure of DNA. Nature 362 709-715.

Möller, P., Larsen, N.K., Kjær, K.H., Funder, S., Schomacker, A., Linge, H., Fabel, D. 2010. Early to middle Holocene valley glaciations on northernmost Greenland. Quat. Sci. Rev. 29, 3379-3398.

Nielsen, U.N., Wall, D.H., 2013. The future of soil invertebrate communities in pola regions: different climate change responses in the Arctic and Antarctic? Ecol. Lett. 16, 409-419.

Oksanen, J., Blanchet, F.G., Kindt, R., Legendre, P., Minchin, P.R., O'Hara, R.B. Simpson, G.L., Solymos, P., Stevens, M.H.H., Wagner, H., 2013. Vegan: Community Ecology Package. $\mathrm{R}$ package Version 2.0-7. http://CRAN.R-project.org/ package = vegan.

Olsen, J., Kjær, K.H., Funder, S., Larsen, N.K., Ludikova, A., 2012. High-Arctic climate conditions for the last 7000 years inferred from multi-proxy analysis of the Bliss Lake record, North Greenland. J. Quat. Sci. 27, 318-327.

Pääbo, S., Poinar, H., Serre, D., Jaenicke-Despres, V., Hebler, J., Rohland, N., Kuch, M., Krause, J., Vigilant, L., Hofreiter, M., 2004. Genetic analyses from ancient DNA Annu. Rev. Genet. 38, 645-679.

Parducci, L., Jørgensen, T., Tollefsrud, M.M., Elverland, E., Alm, T., Fontana, S.L., Bennett, K.D., Haile, J., Matetovici, I., Suyama, Y., Edwards, M.E., Andersen, K. Rasmussen, M. Boessenkool, S., Coissac, E., Brochmann, C. Taberlet, P., Houmark-Nielsen, M., Larsen, N.K., Orlando, L., Gilbert, M.T.P., Kjær, K.H., Alsos, I.G., Willerslev, E., 2012. Glacial survival of boreal trees in Northern Scandinavia. Science 335, 1083-1086.

Parducci, L., Matetovici, I., Fontana, S.L., Bennett, K.D., Suyama, Y., Haile, J., Kjær, K.H. Larsen, N.K., Drouzas, A.D., Willerslev, E., 2013. Molecular- and pollen-based vegetation analysis in lake sediments from central Scandinavia. Mol. Ecol. 22 3511-3524.

Pedersen, M.W., Ginolhac, A., Orlando, L., Olsen, J., Andersen, K., Holm, J., Funder, S. Willerslev, E., Kjaer, K.H., 2013. A comparative study of ancient environmenta DNA to pollen and macrofossils from lake sediments reveals taxonomic overlap and additional plant taxa. Quat. Sci. Rev. 75, 161-168.

Perren, B.B., Wolfe, A.P., Cooke, C.A., Kjaer, K.H., Mazzucchi, D., Steig, E.J., 2012 Twentieth-century warming revives the world's northernmost lake. Geology 40, 1003-1006.

Popp, M., Mirré, V., Brochmann, C., 2011. A single Mid-Pleistocene long-distance dispersal by a bird can explain the extreme bipolar disjunction in crowberries (Empetrum). Proc. Natl. Acad. Sci. U. S. A. 108, 6520-6525.
R Core Team, 2013. R: a Language and Environment for Statistical Computing. R Foundation for Statistical Computing, Vienna, Austria. http://www.R-project. org/.

Rao, C.R., 1995. A review of canonical coordinates and alternative to correspondence analysis using Hellinger distance. Qüestiió 19, 23-63.

Rasmussen, M., Li, Y.R., Lindgreen, S., Pedersen, J.S., Albrechtsen, A., Moltke, I., Metspalu, M., Metspalu, E., Kivisild, T., Gupta, R., Bertalan, M., Nielsen, K., Gilbert, M.T.P., Wang, Y., Raghavan, M., Campos, P.F., Kamp, H.M., Wilson, A.S., Gledhill, A., Tridico, S., Bunce, M., Lorenzen, E.D., Binladen, J., Guo, X.S., Zhao, J., Zhang, X.Q., Zhang, H., Li, Z., Chen, M.F., Orlando, L., Kristiansen, K., Bak, M., Tommerup, N., Bendixen, C., Pierre, T.L., Gronnow, B., Meldgaard, M., Andreasen, C., Fedorova, S.A., Osipova, L.P., Higham, T.F.G., Ramsey, C.B., Hansen, T.V.O., Nielsen, F.C. Crawford, M.H., Brunak, S., Sicheritz-Ponten, T., Villems, R., Nielsen, R., Krogh, A., Wang, J., Willerslev, E., 2010. Ancient human genome sequence of an extinct Palaeo-Eskimo. Nature 463, 757-762.

Round, F.E., Crawford, R.M., Mann, D.G., 1990. The Diatoms - Biology and Morphology of the Genera. Cambridge University Press, Cambridge.

Smol, J.P., 1983. Paleophycology of a high Arctic lake near Cape Herschel, EllesmereIsland. Can. J. Botany-Revue Can. De Bot. 61, 2195-2204.

Smol, J.P., Cumming, B.F., 2000. Tracking long-term changes in climate using algal indicators in lake sediments. J. Phycol. 36, 986-1011.

Smol, J.P., Wolfe, A.P., Birks, H.J.B., Douglas, M.S.V., Jones, V.J., Korhola, A., Pienitz, R., Ruhland, K., Sorvari, S., Antoniades, D., Brooks, S.J., Fallu, M.A., Hughes, M., Keatley, B.E., Laing, T.E., Michelutti, N., Nazarova, L., Nyman, M., Paterson, A.M., Perren, B., Quinlan, R., Rautio, M., Saulnier-Talbot, E., Siitonen, S., Solovieva, N., Weckstrom, J., 2005. Climate-driven regime shifts in the biological communities of arctic lakes. Proc Natl. Acad. Sci. U. S. A. 102, 4397-4402.

Soininen, E.M., Gauthier, G., Bilodeau, F., Berteaux, D., Gielly, L., Taberlet, P., Gussarova, G., Bellemain, E., Hassel, K., Stenøien, H.K., Epp, L.S., SchrøderNielsen, A., Brochmann, C., Yoccoz, N.G., 2015. Highly overlapping winter diet in two sympatric lemming species revealed by DNA metabarcoding. PLoS One 10 e0115335.

Sønstebø, J.H., Gielly, L., Brysting, A.K., Elven, R., Edwards, M., Haile, J., Willerslev, E., Coissac, E., Rioux, D., Sannier, J., Taberlet, P., Brochmann, C., 2010. Using nextgeneration sequencing for molecular reconstruction of past Arctic vegetation and climate. Mol. Ecol. Resour. 10, 1009-1018.

Stoof-Leichsenring, K.R., Epp, L.S., Trauth, M.H., Tiedemann, R., 2012. Hidden diversity in diatoms of Kenyan Lake Naivasha: a genetic approach detects temporal variation. Mol. Ecol. 21, 1918-1930.

Suyama, Y., Gunnarsson, U., Parducci, L., 2008. Analysis of short DNA fragments from Holocene peatmoss samples. Holocene 18, 1003-1006.

Taberlet, P., Coissac, E., Hajibabaei, M., Rieseberg, L.H., 2012. Environmental DNA. Mol. Ecol. 21, 1789-1793.

Taberlet, P., Coissac, E., Pompanon, F., Gielly, L., Miquel, C., Valentini, A., Vermat, T., Corthier, G., Brochmann, C., Willerslev, E., 2007. Power and limitations of the chloroplast trnL (UAA) intron for plant DNA barcoding. Nucleic Acids Res. 35, e14.

Valentini, A., Pompanon, F., Taberlet, P., 2009. DNA barcoding for ecologists. Trends Ecol. Evol. 24, 110-117.

Vorren, T.O., Vorren, K.D., Aasheim, O., Dahlgren, K.I.T., Forwick, M., Hassel, K., 2013. Palaeoenvironment in northern Norway between 22.2 and 14.5 cal. ka BP. Boreas 42, 876-895.

Wagner, B., Bennike, O., Bos, J.A.A., Cremer, H., Lotter, A.F., Melles, M., 2008. A multidisciplinary study of Holocene sediment records from Hjort Sø on Store Koldewey, Northeast Greenland. J. Paleolimnol. 39, 381-398.

Wall, D.H., 2007. Global change tipping points: above- and below-ground biotic interactions in a low diversity ecosystem. Philos. Trans. R. Soc. B-Biol. Sci. 362, 2291-2306.

Willerslev, E., Hansen, A.J., Binladen, J., Brand, T.B., Gilbert, M.T.P., Shapiro, B., Bunce, M., Wiuf, C., Gilichinsky, D.A., Cooper, A., 2003. Diverse plant and animal genetic records from Holocene and Pleistocene sediments. Science 300, 791-795.

Willerslev, E., Hansen, A.J., Poinar, H.N., 2004. Isolation of nucleic acids and cultures from fossil ice and permafrost. Trends Ecol. Evol. 19, 141-147.

Willerslev, E., Davison, J., Moora, M., Zobel, M., Coissac, E., Edwards, M.E., Lorenzen, E.D., Vestergard, M., Gussarova, G., Haile, J., Craine, J., Gielly, L., Boessenkool, S., Epp, L.S., Pearman, P.B., Cheddadi, R., Murray, D., Brathen, K.A. Yoccoz, N., Binney, H., Cruaud, C., Wincker, P., Goslar, T., Alsos, I.G., Bellemain, E., Brysting, A.K., Elven, R., Sonstebo, J.H., Murton, J., Sher, A., Rasmussen, M., Ronn, R., Mourier, T., Cooper, A., Austin, J., Moller, P., Froese, D., Zazula, G., Pompanon, F., Rioux, D., Niderkorn, V., Tikhonov, A., Savvinov, G., Roberts, R.G., MacPhee, R.D.E., Gilbert, M.T.P., Kjaer, K.H., Orlando, L., Brochmann, C., Taberlet, P., 2014. Fifty thousand years of Arctic vegetation and megafaunal diet. Nature 506, 47.

Willis, K.J., Bailey, R.M., Bhagwat, S.A., Birks, H.J.B., 2010. Biodiversity baselines, thresholds and resilience: testing predictions and assumptions using palaeoecological data. Trends Ecol. Evol. 25, 583-591.

Xie, C.F., Lou, H.X., 2009. Secondary metabolites in bryophytes: an ecological aspect. Chem. Biodivers. 6, 303-312.

Xu, Z.H., Jiang, X.D., Wang, G.Z., He, J.F., Cai, M.H., Wu, L.S., Jiang, J.L., Chen, X.L., 2011. DNA extraction, amplification and analysis of the 28S rRNA portion in sediment-buried copepod DNA in the Great Wall Bay and Xihu Lake, Antarctica. J. Plankton Res. 33, 917-925. 